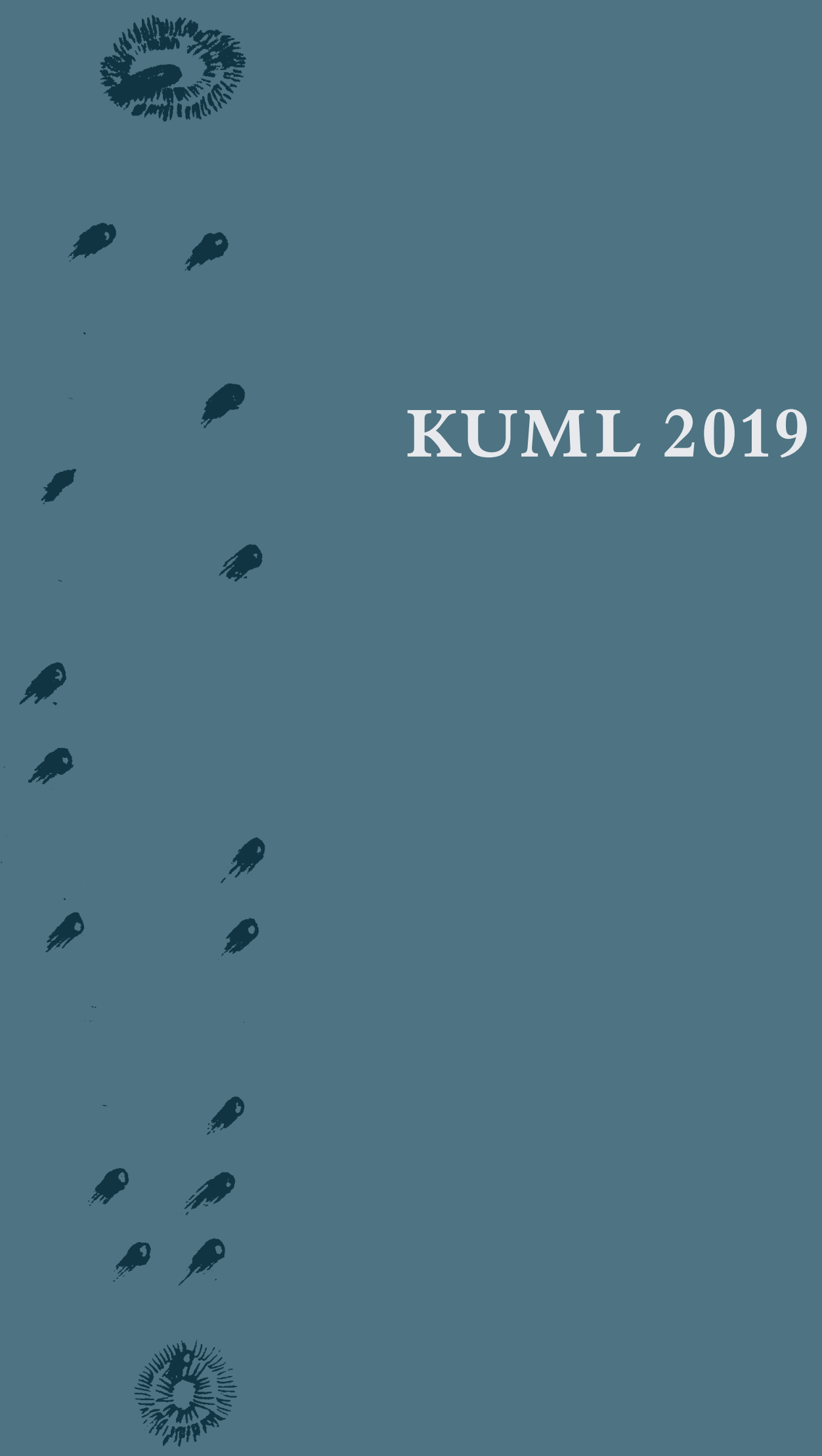

KUML 2019 


\section{KUML 2019}

Årbog for Jysk Arkæologisk Selskab

With summaries in English

I kommission hos Aarhus Universitetsforlag 


\section{Troldtøj og guldfigurer \\ Om et par nye tolkninger af fund fra germansk jernalder i lyset af nyere tids sagn}

Ad to omgange sidst på året 2018 bragte tidsskriftet Skalk og websitet Videnskab.dk i fælleskab to artikler, hvori seniorforsker på Nationalmuseet, Flemming Kaul, fremlagde sine tolkninger af de senere års fund af guldgubber fra lokaliteten med det velvalgte navn Guldhullet, ved Smørenge på Bornholm. Lanceringen af hypoteserne nåede vidt og bredt ud i medielandskabet, og må siges at være et succesrigt eksempel på forskningsformidling af et nicheområde. ${ }^{1}$

Meget af successen udpringer givetvis af det faktum, at der er tale om spændende hypoteser, der behandler muligheden for at bringe jernalderens gådefulde billedverden i forbindelse med det både velkendte, men også eksotiske folkesagnsmateriale, der ligger så tæet på vores egen tid, men dog så fjernt fra vores moderne mentalitet. Kaul bringer således de i nutidig populærkultur velkendte, skiftevist hyggelige og uhyggelige trolde på banen sammen med en kvindelig figur velkendt på Næstvedegnen med det fantasiæggende navn "Slattenlangpat".

Kort opsummeret tolker Kaul i den første artikel en lille kvindelig guldfigurine som Slattenlangpat, der i sagnene konstant jages af en rytter, ofte kaldet Kong Volmer. Dette sagn går ifølge Kaul tilbage til førkristen tid, hvor der bag Kong Volmer gemmer sig den gamle gud Odin, mens Slattenlangpat, der egentlig er en ellekone, oprindeligt skal forstås som en frugtbarheds- eller flodgudinde. I den anden artikel tolker Kaul en lille gruppe guldgubber med et hidtil ukendt motiv, nemlig figurer med ansigtet placeret nede i kroppen. Disse figurer identificeres som trolde i lyset af våbenskjoldet for adelsslægten Trolle, med billedet af en halshugget trold forsynet med et ansigt i maven, et billede der refererer til sagnet om, hvordan slægten fik sit navn efter stamfaderens opgør med dette uhyre. Også her kan der etableres forbindelse til en førkristen gud, da tordenguden Tor stadig i nyere tids sagn fortsætter sin jagt på trolde, præcis som det kendes fra de ældste kilder til den nordiske mytologi. 
De to tolkninger forenes i en hypotese om, at de kvindelige guldfigurer kan opfattes som votivgaver specifikt rettet til guden Odin, mens de troldelignende guldgubber er votivgaver til Tor.

Kaul er tydelig omkring, at der er tale om hypoteser, og at det at benytte nyere tids sagn til at tolke yngre jernalders ikonografi indeholder metodiske vanskeligheder. Det fremgår dog, at det er et bevidst metodisk valg, når Kaul går direkte til nyere tids sagnmateriale uden først at undersøge figurerne i sammenhæng med samtidigt ikonografisk materiale. ${ }^{2}$ Dette metodiske fravalg indebærer dog stor risiko for, at tolkeren kan blive bjergtaget af nyere tids folklore, hvor ikke alt, der ligner gammel hedenskab, tåler nærmere belysning.

Hos overtegnede efterlader disse hypoteser således flere spørgsmål end svar. I den følgende kritik vil jeg derfor forsøge både at følge Kaul ved som han at prøve at tilegne mig sagnstoffet samt kort fremlægge alternativer til de diskuterede hypoteser, der tager udgangspunkt i guldfigurernes parallelmateriale fra den yngre jernalder og sammenligninger med ældre skriftlige kilder.

\section{Guldfigurinen fra Guldhullet}

Som det fremgår af en tidligere præsentation af René Laursen fra Bornholms Museum, er guldfigurinen 4,2 cm høj og vejer 3 gram (fig. 1). ${ }^{3}$ Figurinen, der er nøgen på nær et bredt bælte om livet, har en slank og langstrakt kropsform. Ansigtet har et fremstrakt kæbeparti. Armene befinder sig langs kroppens sider, og håndfladerne er placeret på bugen med strittende tommelfingre vendt mod hinanden. Benene er strakte med nedadvendte fødder. Bryster og vulva er tydeligt markeret. En vigtig iagttagelse, som fremhæves af René Laursen, er et tydeligt indhak, som ses under begge skuldre, "som om armene har været snøret ind til kroppen”. ${ }^{4}$ Ryggen på figuren er bemærkelsesværdig. Kaul beskriver "den kraftigt indadbøjede ryg" med "en hulhed i ryggen, så ryghvirvlerne er tydelige." ${ }^{5}$ Både René Laursen og Kaul er enige om, at brysterne er "hængende" ${ }^{6}$, hvilket, vi må forstå, er det, der leder Kaul til at associere til sagnfiguren Slattenlangpat, mens den "hule ryg" associerer til folketroens ellepiger. Men er der virkelig tale om "hængebryster"? Og er figuren decideret hulrygget? I modsætning til sagnenes beskrivelser hænger brysterne tydeligvis ikke ned til bæltestedet - de når kun ned til midt på torsoen. Hvis det, som René Laursen foreslår, er korrekt, at indhakket ved skuldrene angiver, at armene har været snøret ind til kroppen, kan det måske bedre forklare det særlige visuelle udtryk, som figurens attributter har fået? At kalde dem for "hængepatter" virker dog ikke rimeligt, ej heller at kalde figuren hulrygget. Der er nærmere tale om, at figuren svajer i ryggen, eller indtager en lettere akrobatisk positur. 


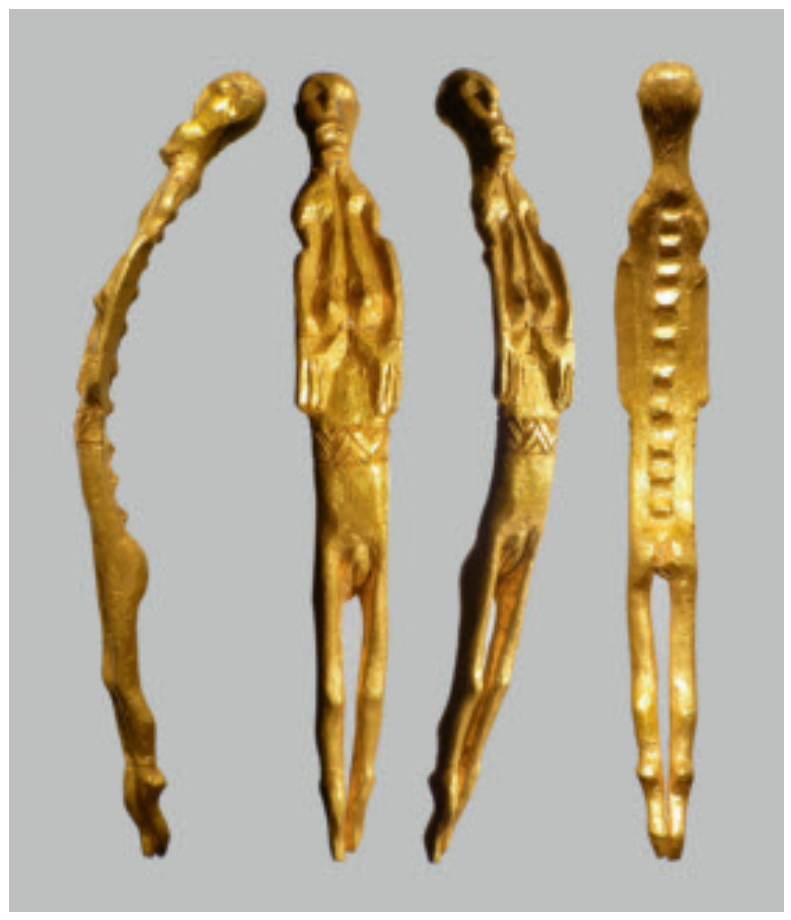

Fig. 1. Guldfigurine fra Guldhullet, Smørenge, Bornholm. - Foto: René Laursen, Bornholms Museum.

At man kan se ryghvirvlerne er heller ikke et tegn på en hul ryg, vel nærmest tværtimod. Den svajede ryg med udstikkende ryghvirvler passer overens med den slanke, ja nærmest magre kropsform.

Efter denne kritiske ikonografiske beskrivelse af guldfigurinen skal vi nu se nærmere på det sagnmateriale, som Kaul inddrager i sin tolkning, nemlig komplekset omkring det såkaldte kvindejagtsagn og dets to hovedpersoner, den vilde jæger og hans kvindelige bytte, og ikke mindst spørgsmålet om deres identitet og oprindelse.

\section{Kvindejagten}

Vandresagnet om en rytters natlige jagt på et kvindeligt væsen er blevet tolket og diskuteret siden folkemindevidenskabens barndom, uden at der er opnået konsensus om, hvorvidt sagnet kan knyttes til førkristne forestillinger om Odin. Kauls inddragelse af nye vidnesbyrd i form af arkæologiske fund med henblik på tolkningen af den ovennævnte guldfigurine må derfor evalueres i forhold til denne debat. Vi bevæger os således nu ind over grænsen mellem arkæologi og folkemindevidenskab. 
"Den vilde jagt", "Die Fraunjagdsage" eller "The Farie Hunt" er et udbredt vandresagn, der kendes fra Tyskland, Irland og Skandinavien, især fra folkesagn fra det 19. og tidlige 20. århundrede. I Skandinavien er sagnet sjældent i Norge, men kendes i ca. 27 varianter fra Danmark og i 256 varianter fra den sydlige del af Sverige. Sagnets kerne består af en overnaturlig jægers jagt på et kvindeligt bytte, hvor et menneskeligt vidne på forskellig vis indblandes. I nordtyske og jyske varianter er der ofte tale om, at en natlig vandrer ser to kvinder løbe forbi, hvor han overhører den ene sige til den anden, at den vilde jæger ikke kan nå dem, da han er uvasket. Kort efter møder vandreren den vilde jæger, der spørger, om han har set nogen løbe forbi. Vandreren bekræfter, og fortæller jægeren om deres ordveksling. Vandreren henter da vand til jægeren at vaske sig i, eller jægeren vasker sig i sit eget vand, hvorefter det lykkes at fange de to kvinder, der kastes over sadlen bundet sammen ved deres lange hår. Andre måder, hvorved vandreren kan assistere den vilde jæger, er ved at holde eller fodre hans jagthunde. Ofte består hjælpen blot i at lede jægeren i den rigtige retning. Den hjælpsomme vandrer modtager ofte en belønning af jægeren, såsom gloende mønter eller en hestesko, der ved dagslys viser sig at være af guld eller sølv, osv. I dele af Tyskland kan vandreren som tak for hjælp sågar modtage et stykke af det parterede jagtbytte. På de danske øer og i Sverige er der som regel kun tale om et enkelt kvindeligt jagtbytte. Velkendt blandt de skandinaviske varianter, men ukendt i resten af udbredelsesområdet, er motivet med jagtbyttets lange bryster, der slæber langs jorden, hænger ned til bæltet, eller som oftest slynges over skuldrene. ${ }^{7}$

Der er tidligere gjort forsøg på at føre kvindejagtsagnet tilbage til førkristne nordiske myter med henvisning til, at Freya i Snorres Edda siges at søge efter sin forsvundne mand Óðr. ${ }^{8}$ Forholdet er dog her omvendt - i myten er det kvinden, der eftersøger manden - og om decideret jagt og nedlæggelse, som er den dramatiske kerne i sagnet, er der ingen tale om. Der synes i det hele taget ikke at kunne påvises forbilleder i nordiske førkristne myter for kvindejagtsagnet.

Meget tyder derimod på, at sagnet har sin oprindelse i højmiddelalderlige exempla, dvs. korte moralsk-pædagogiske historier, der cirkulerede blandt de gestlige til brug i prædikener. Tætte paralleller til kvindejagtsagnet kendes således fra to cisterciensermunke, Helinand de Froidmont (ca. 1156-1229) og Cesarius von Heisterbach (ca. 1180-1240).

Den første historie handler om en fattig, men from kulsvier fra Nevers i Bourgogne. En nat, mens han passer sin mile, ser han en nøgen kvinde løbe forbi forfulgt af en soldat ridende på en sort hest. Soldaten indhenter kvinden, griber hende ved hendes udslåede hår, støder sit sværd igennem hende og 
kaster hende i milen. Soldaten hiver den forbrændte kvindekrop ud af milen, smider hende over sadlen og rider bort. Efter at have set det samme optrin tre nætter i træk, fortæller kulsvieren sin greve om sine visioner. Greven følger med kulsvieren til hans mile og ser den følgende nat optrinnet med egne øjne. Da soldaten er ved at ride bort, tager greven mod til sig og henvender sig til soldaten og spørger ham om meningen med den vision, de har været vidne til. Soldaten forklarer, at dette er den straf, som han og kvinden skal sone. Selv var han en ridder ved grevens hof, og kvinden var hans elskerinde, der myrdede sin mand. Hesten er en dæmon, som er betroet hvervet med at torturere de ulykkelige sjæle. ${ }^{9}$

Den anden historie fortæller om en elskerinde til en præst i domstiftet Mainz, der på sit dødsleje ønskede at få et par gode nye sko på i graven. Natten efter begravelsen møder en ridder en kvinde på sin vej, der råber efter hjælp. Ridderen genkender kvinden, stiger af hesten og trækker sit sværd for at beskytte hende. Pludselig høres der jagthorn og hundegøen i natten. Ridderen vikler da kvindens hår omkring sin venstre arm og holder fast. Da en diabolsk jæger nærmer sig, råber kvinden, at han skal slippe hende løs, men ridderen holder fast. Kvinden slider sig dog fri, så ridderen står tilbage med hendes hår. Djæevlen rider forbi og indhenter kvinden, som han kaster over sadlen og rider bort med. Da ridderen fortæller sin historie, beslutter man sig for at åbne kvindens grav og ser, at hun mangler sit hår. ${ }^{10}$

Disse to historier, der udgør de ældste versioner af kvindejagtsagnet, har en klar kristen moralsk kontekst. Som det ses, er jagtbyttet en kvinde, der har begået utugt eller andre synder og derfor soner sin forbrydelse ved en djævelsk mellemkomst. I de senere versioner af sagnet fra nyere tid er jægeren selv ofte dømt til at jage de kvindelige væsner, enten fordi han syndede ved at jage på helligdage, eller fordi han på sit dødsleje selv ønskede at jage til dommedag. ${ }^{11}$ I stedet for et ekko af en nordisk førkristen myte er sagnet om kvindejagten altså formentlig opstået som en folkelig videreudvikling af en historie med en kristen morale, der stammer fra det store udland og oprindeligt blev spredt gennem middelalderens kirkevæsen.

\section{Er den vilde jæger Odin?}

Kaul mener som sagt, at den vilde jæger formodentlig har "rod i Odin eller den germanske gud Wotan". ${ }^{12}$ I Nordtyskland og Skandinavien går den vilde jæger da også ofte under navne, der antyder en sådan forbindelse: I Nordtyskland Wode, Wod, Wodke og lignende, i Jylland Wojensjægeren, Hoensjægeren, Joensjæger, Un osv., i Sverige Oden, Oan, Hoan, Jon, Noen m.fl. I 
sagnforskningen kendes han derfor ofte slet og ret som Odinsjægeren. Blandt folkemindeforskerne er spørgsmålet, om den vilde jæger har noget med en oprindelig førkristen Odin at gøre dog uafklaret. ${ }^{13}$

At Odin har et langt efterliv i det kristne Norden er dokumenteret på forskellig vis i både middelalderens og nyere tids trolddomsforestillinger samt i folketroen, f.eks. ved skikken at sætte høstens sidste neg ud til Odins hest. ${ }^{14}$ Andre danske og svenske sagn knyttet til den vilde jæger er hans larmende ridt gennem luften om efteråret og vinteren, der ofte kun høres, men ikke ses, fulgt af sine gøende himmelhunde. I nogle sagn følger han bestemte ruter på landjorden. I begge tilfælde gælder det om ikke at stå i vejen for hans jagt. Hvis man lader gårdens porte stå åbne, risikerer man desuden, at den vilde jæger eller hans hunde farer igennem gården. ${ }^{15}$ Alderen på disse sagn er svær at afgøre, og deres tilknytning til den førkristne Odin synes ikke selvindlysende. Lignende sagn kendes fra store dele af Vesteuropa. At der måske ikke er tale om en fast tilknytning mellem aseguden og dette sagnkompleks antydes ved den mængde af forskellige figurer, der siges at anføre jagten. I Danmark: Kong Volmer (dvs. Valdemar Atterdag), Kong Abel, Palle Jæger, Grønjætte, Jøen Upsal, Klintekongen; i udlandet f.eks.: Skt. Hubertus, Kong Arthur, Herodes, Karl den Store, Didrik af Bern osv. I flere sagn er der sågar tale om genfærdet af en lokal greve eller jagtmester, der jager. Både i Norden og på Kontinentet er jægeren ofte ingen anden end Djæevlen selv. ${ }^{16}$

I Nordtyskland og Skandinavien er der for det meste tale om en solitær skikkelse; i England, Frankrig og Sydtyskland findes der lignende sagn om larmende fænomener i natten, men her i større jagtselskaber, hærtropper eller skarer af dødninge og fortabte sjæle. I Sydtyskland kaldes dette fænomen for das wïtende Heer, dvs. den rasende hær. Netop sammenligningen mellem de nordtyske og skandinaviske sagn, hvor lederen har Wotan- eller Odinlignende navne, og sydtyskernes wütende Heer, var det, der tilbage i 1835 fik en af folkemindevidenskabens fædre, Jacob Grimm, til at foreslå, at lederen for dødningehæren i sydtysk tradition var Wotan selv, da navnet på guden og navnet for hæren havde samme oprindelse, nemlig i adjektivet "wut", dvs. raseri. ${ }^{17}$ I det 20. århundrede har den østrigske forsker Otto Höflers teori om en ældgammel sammenhæng mellem Odin-kult og folkesagnene om de rasende hære og den vilde jæger desuden været meget indflydelsesrig..$^{18}$ Grimms hypotese anses dog i dag af mange for en lærd konstruktion, ligesom Höflers værk siden udgivelsen i 1934 har været meget kontroversiel. ${ }^{19}$

Det er således langt fra sikkert, at den vilde jæger har rod i den førkristne Odin og tilknyttede forestillinger. Selv om dette skulle være tilfældet for andre dele af det større sagnkompleks omkring rasende hære og støjende optog 
i natten, er sammenhængen mellem Odin og sagnet om kvindejagten højst sandsynligt sekundær. Som figur i kvindejagtsagnet er Odin altså lige så oprindelig som Kong Volmer.

\section{Er Slattenlangpat en elverkone?}

Men hvad så med jægerens bytte - kan hun siges at være en skikkelse, der går tilbage til førkristen tid, og hvad er hendes nærmere identitet? Kaul mener, at hun på den ene side er "af elverfolket", dog "ikke en elverpige, men en elverfrue eller elverdame. Hun betegnes herved som lidt ældre, mere moden, hvad de hængende bryster jo også angiver.” Kaul mener desuden, at Slattenlangpat især er knyttet til "den sydsjællandske Suså, hvor hun bedst kan forstås som en slags flodgudinde", hvor hendes lange bryster symboliserer frugtbarhed. ${ }^{20}$ Før vi undersøger disse påstande, skal der anføres nogle generelle forhold omkring Slattenlangpat og hendes slægtninge, både udenfor og i sammenhæng med kvindejagtsagnet.

Kvindejagtsagnet er som nævnt kendt over et stort område. Jagtbyttet er ofte forskellige overnaturlige kvindeskikkelser, alt efter lokale traditioner, men det er ifølge folkemindeforskeren Lutz Röhrich kun i skandinaviske varianter, at vi finder motivet med de lange bryster. Ud af 283 varianter af sagnet i Danmark og Sverige indeholder 71 varianter motivet med de lange bryster. Motivet kendes i kvindejagtsagnet ifølge Axel Olrik desuden ikke fra Jylland. ${ }^{21}$

Motivet med de usædvanligt lange bryster, der f.eks. kan slynges over skuldrene ved løb eller for at die en unge, der hænger på ryggen, er på den anden side et træk, der kendes vidt og bredt hos forskellige overnaturlige væsner i andre sammenhænge end kvindejagtsagnet. De lange bryster findes i Evald Tang Kristensens samling af danske sagn i flere sammenhænge uden sammenhæng med kvindejagtsagnet og er her knyttet til både ellefolk, bjergfolk og puslinger. ${ }^{22}$ Fænomenet er også kendt fra slavisk område, f.eks.

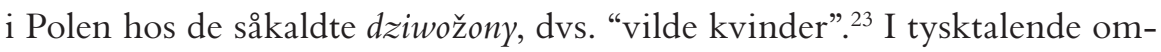
råder er de lange bryster forbundet med forskellige overnaturlige væsner, der kan være farlige for børn, såsom Tyrols Langtiittin, der løber efter børn og byder dem sine lange bryster, hvorfra der løber mælk fra det ene og gift fra det andet, eller de kvindelige korndæmoner med forskellige navne som Roggenmuhme eller Tittenwief, der spidder børn med deres bryster eller brystvorter af jern, eller Kornmutter, der tvinger børn at die hendes brændende bryster. ${ }^{24}$ I Skotland siges det uheldsvangre væsen Bean Nighe at kaste sine lange bryster over skuldrene, når hun vasker tøj. ${ }^{25}$ De lange eller på anden måde usædvanlige bryster er altså ikke et særtræk for jagtbyttet i kvinde- 
jagtsagnet, og for det andet synes det ikke oplagt, at de signalerer noget positivt. Snarere er der tale om noget, der signalerer hæslighed og andethed, et monstrøst eller dæmonisk træk, noget der udgrænser de overnaturlige væsner fra menneskesamfundet. ${ }^{26}$

På samme måde, som det navngivende træk ved Slattenlangpat ses at være et vidt spredt træk ved overnaturlige kvindelige væsner, er der heller ikke meget, der synes at knytte hende specifikt til ellefolket. At ellefolkets kvinder kan deles op i en yngre aldersgruppe, ellepiger, og en ældre aldersgruppe, ellekoner, der karakteriseres ved deres lange bryster, og at Slattenlangpat dermed er en ellekone, kan læses hos Holbek og Piø i Politikens håndbog om fabeldyr og sagnfolk, der muligvis er Kauls kilde på dette punkt. ${ }^{27}$ Ellekvinder beskrives ganske rigtig flere gange med lange bryster, som kan kastes over skuldrene under løb, eller hvis de vil die deres børn, mens de hænger på deres ryg. ${ }^{28}$ Som bekendt er et karakteristisk træk ved ellefolket deres grimme rygge, der er hule som dejtrug, hvilket i beskrivelserne sættes i kontrast til ellepigernes skønne forside..$^{29}$ Kun en enkelt gang i Tang Kristensens samling er en ellekvinde beskrevet med både lange bryster og hul ryg, altså hvor andetheden vises fra begge sider. ${ }^{30} \mathrm{I}$ en jysk version af kvindejagten gemmer en ellekvinde sig i stuen hos en kvinde i barselssengen, indtil jægere er reddet forbi, og da hun forlader barselsstuen, ser den barslende kvinde, at gæsten har en hul ryg. ${ }^{31}$ Som nævnt indeholder ingen af de jyske varianter af sagnet dog motivet med de lange bryster. I Gunnar Granbergs undersøgelse af det svenske sagnvæesen skogsrået, der er et væsen beslægtet med det danske ellefolk, findes i de mange svenske varianter af kvindejagtsagnet ingen eksempler på den hule ryg eller halen, som ellers er karakteristisk for dette væsen, og han konkluderer, at skogsråets tilknytning til dette sagn må være sekundær. ${ }^{32}$ Mig bekendt er der ligeledes ingen eksempler på, at Slattenlangpat har hul ryg, og dermed falder det mest karakteristiske træk tilhørende ellefolket bort som argument for, at Slattenlangpat tilhører denne kategori.

\section{Er Slattenlangpat en flod- eller frugtbarhedsgudinde?}

Idéen om, at Slattenlangpat ud over at være en lokal sydsjællandsk sagnfigur skulle være særligt knyttet til Susåen, er, så vidt jeg kan se, ikke noget, der fremgår tydeligt af kilderne. Oplysningen findes dog i forbindelse med omtaler af billedkunstner Bjørn Nørgaards vandkunst på Næstved Torv, "Slattenpat og hendes døtre", hvor hun ses som "et sindbillede på Susåens rindende vande."33 Kaul underbygger sin hypotese om Slattenlangpat som en art flodgudinde med sagnet tilknyttet "Slage-Langpattes Sten" ved Everdrup Præsteskov, som 
Slattenlangpat lagde sig ud over for at give die til sine to børn, der var halvt fisk og måtte opholde sig i vandet. ${ }^{34}$

Et andet sagn, som Kaul anvender i sin bevisførelse for Slattenlangpats positive guddommelige egenskaber, er en variant af kvindejagtsagnet, hvor en karl hjælper Kong Valdemar med at fange Slattenpat. Da jægeren kommer tilbage med det nedlagte bytte over sadlen, får karlen som tak for hjælpen anvisning om at die fruentimmeret. Dette giver karlen overnaturlig styrke, der gør, at han kan sætte sin tyranniske husbond på plads. ${ }^{35}$ Mod tolkningen af dette som bevis på hendes guddommelige status må det bemærkes, at der ikke er tale om et aktivt valg fra Slattenlangpats side om at begunstige karlen, men at det er den vilde jæger, der som sædvanlig belønner sin hjælper. Fremfor at se den store styrke, der overføres til karlen, som et positivt træk ved Slattenlangpat, er der snarere tale om, at motivet skal afspejle hendes uhyrlighed. Motivet minder om episoden i Rolf Krakes saga, hvor Bødvar fælder den drage, der hærger kongens hal ved juletid, og får Hat til at drikke af dens blod og spise af dens hjerte, hvorefter han får kæmpekræfter og derefter ikke længere kan terroriseres af kongens hirdmænd. ${ }^{36}$ Her er der ingen tvivl om, at dragen er et monster og ikke en guddom.

At de lange bryster på kvinden, der jages af den vilde jæger, bør anses for frugtbarhedssymboler, er en idé der går tilbage til Wilhelm Mannhardt i hans storværk, "Wald und Feldtkulte" fra 1875. Mannhardt tolker her de forskellige overnaturlige væsner som vegetationsdæmoner knyttet til skovene, og deres lange bryster "als ein sinnlich symbolischer Ausdruck der Vegetationsfülle". ${ }^{37}$ Mannhardts teorier tilhører et overstået kapitel i folkemindeforskningen og har i dag mest interesse som materialesamling samt forskningshistorisk. ${ }^{38}$

En anden inspirationskilde for Kauls tolkning af Slattenlangpat som en gammel frugtbarhedsgudinde kan være Axel Olrik og Hans Ellekildes "Nordens Gudeverden” fra 1926-1951. Med udgangspunkt i de svenske sagn om skogsrået, der som de danske ellepiger optræder erotisk fristende og desuden kan give jægerne jagtlykke, forestiller Olrik og Ellekilde sig, at denne forestilling går tilbage til en "primitiv-erotisk jægertro" fra mesolitisk tid, om "et væsen i kvindeskikkelse ude i skoven, en kvinde med vældige bryster, der gav jagtlykke til den mand, som vandt hendes gunst ved at stille hendes elskovshunger." Med tiden begyndte bondebefolkningen at opfatte dette væsen mere negativt, heraf det hånlige sjællandske navn "Slattenlangpatte". Det ses, at Olrik og Ellekilde er bevidste om, at skogsrået, ganske som de danske ellepiger, i svenske sagn viser sig for de enlige jægere eller kulsviere som en skøn ung kvinde, hvilket skyldes, at skogsrået "i årtusindernes løb [har] afstrøget det oprindelige barbariske skönhedspræg”. Videre forsøger Olrik og Ellekilde at skabe en forbindelse 
mellem denne hypotetiske figur og Tacitus' bekendte beskrivelse fra år 98 e.Kr. af germanernes kult til ære for gudinden Nerthus. Denne evolutionistiske historiske rekonstruktion virker dog lidet overbevisende. ${ }^{39}$

Det er dog ikke umuligt, at der bag sagnet om Slattenlangpats diende fiskebørn ligger en bestemt forestilling knyttet til en førkristen gudinde. Fra middelalderens kirkekunst kendes nemlig gengivelser af kvinder, der dies af slanger, vilddyr eller hybride monstre, såsom basilisker. Disse opfattes i forskningen, med henvisning til middelalderens visionslitteratur, gerne som personifikationer af dødssynden Vellyst, Luxuria. De ikonografiske forbilleder er hentet $i$ antikkens fremstillinger af den romerske gudinde Tellus eller Terra Mater, Moder Jord, der ammer forskellige dyr som et billede på jordens frugtbarhed. Kun de ydre ikonografiske træk ved den antikke gudinde er tilbage, indholdet er aldeles forvandlet i den kristne kontekst. ${ }^{40}$ Nogle forskere har påpeget, at det ud fra middelalderens skriftlige kilder ikke så meget er faldne kvinder i almindelighed, men mere præcist kvinder, der f.eks. har slået deres uønskede spædbørn ihjel eller nægtet at amme forældreløse børn i deres varetægt, der pines i Helvede på denne måde. Betegnelsen Luxuria er derfor ikke præcis, nærmere bestemt er der tale om billeder af dårlige eller onde mødre. ${ }^{41}$

Fig. 2. Kvinde dies af basilisker, Birkerød Kirke, Sjælland. - Foto: Hideko Bondesen - http://www. nordenskirker.dk/. Wikimedia Commons.

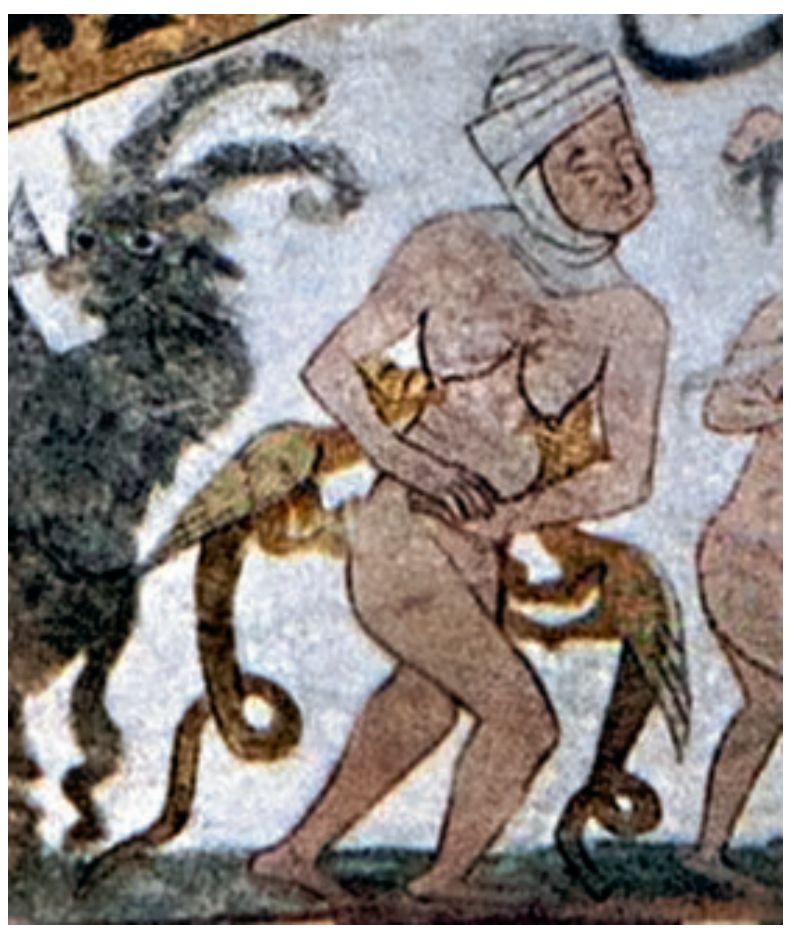


Der er flere kendte billeder af "den dårlige moder" i kerneområdet for motivet med jagtbyttets lange bryster i kvindejagtsagnet, dvs. Sjælland og Sydsverige. Som eksempel på motivet gengives her et kalkmaleri fra Birkerød Kirke (fig. 2). Motivet er især kendt fra romanske døbefonte. I Skåne bl.a. fra døbefontene i Knislinge, Lyngsjö og Östra Hoby kirker, hvor kvinden dies af to slanger eller basilisker, og fra Vester Egede Kirke på Sydsjælland, hvor kvinden er placeret med hovedet nedad og dies af en løve og en basilisk. ${ }^{42}$ Vester Egede ligger blot $8 \mathrm{~km}$ nord for Everdrup, hvortil sagnet om stenen, hvor Slattenlangpat skal die sine børn, er henlagt. Kan de hybride fiskebørn i sagnet være inspireret af fremstillinger af basilisker, der dier den fortabte onde moder? I middelalderens kristne moralske kontekst er der jo ikke langt fra de omtalte exempla med fordømte utugtige kvinder, der soner deres synder ved at blive jaget af dæmoniske jægere, til de onde mødre i visionslitteraturen, der er dømt til at give die til slanger i Helvede. I modsætning til Kaul, der mener, at Slattenlangpat har lange bryster, fordi "hun igennem sit liv har givet frugtbarhed og næring til mange børn", og at hun i sin funktion som flodgudinde dier sine fiskebørn for "at kunne give liv til vand og å", mener jeg snarere, at sagnet om Slage-Langpattes Sten afspejler den sydsjællandske folketros bearbejdning af middelalderens forestilling om den onde moder, der som straf for at have nægtet sine børn die i levende live, efter døden soner ved at give die til monstre. ${ }^{43}$ Noget minde om en førkristen gudinde, såsom romernes Terra, men omformet til en nordisk flodgudinde, mener jeg ikke, der er tale om.

\section{Et alternativ: Guldfigurinen som hængt til Odin}

Hvis man, i stedet for at springe direkte til sammenligninger med nyere tids folklore, forsøger at se guldfigurinen i sammenhæng med samtidig figurkunst i form af brakteater, figuriner og guldgubber fra germansk jernalder, så åbner der sig helt andre perspektiver. Først og fremmest falder figurinen fra Guldhullet naturligt ind i en række af figurer, der er fremstillet som nøgne, på nær måske et bælte om livet og/eller en ring om halsen. Blandt gulbrakteaterne findes det tydeligste eksempel på gruppen af brakteater med tre stående menneskefigurer - ofte benævnes motivet "Victoria bekranser en sejrherre", eller, hvis man følger Karl Haucks tolkning, "Drei-Götterbrakteaten" - hvor den midterste figur er nøgen bortset fra et bredt bælte om livet. ${ }^{44}$ Blandt guldgubberne kan som paralleller nævnes en udskåren gubbe fra kulthuset i Uppåkra, eller flere gubber fra Sorte Muld. ${ }^{45}$ Fra den plastiske kunst kan fremhæves bronzefigurinen fra Køng eller figurinerne fra Lunda, der alle er nøgne mænd med bælter om livet. ${ }^{46}$ Kaul fremhæver 
især kvindelige paralleller til figurinen fra Guldhullet. Kønskvoten blandt de nøgne figuriner og guldgubber synes ikke desto mindre at have en maskulin slagside. At dette er tilfældet, svækker hypotesen om en særlig forbindelse til kvindelige sagnvæsner eller gudinder. Mere oplagt er det, at det snarere end figurernes køn, der er interessant for en identifikation, er deres fællestræk i kropsholdning og beklædning eller mangel på samme, der viser frem mod en fælles bagvedliggende idé. En alternativ tolkning af kvindefiguren fra Guldhullet og hendes nærmeste slægtninge kan dog stadig passes ind i en hypotese centreret omkring Odin-kult.

At guldgubberne generelt fungerer som votivofre eller "tempelpenge" er bredt accepteret. ${ }^{47}$ Både guldgubberne, figurinerne og brakteaternes menneskefigurer tolkes gerne som gudefigurer. Da figurerne imidlertid ikke besidder gode og sikre attributter til at identificere specifikke guddomme fra den nordiske gudelære, er argumentet ofte bygget på netop nøgenheden, der ses som et guddommeligt træk inspireret af de importerede romerske gudestatuetter ${ }^{48}$ En anden mulighed, jeg vil slå til lyd for, er den såkaldte "rituelle nøgenhed", dvs. den nøgenhed, der ofte forekommer i rituelle sammenhænge, typisk i overgangsriter. ${ }^{49}$ Det bedste eksempel relevant for det førkristne Norden er nok Ibn Fadlans beskrivelse af en begravelse blandt Rus, hvor ligbålet tændes af en nøgen mand. ${ }^{50}$ Andre eksempler kunne være moseligene, der ofte er nøgne.

Bronzefigurinen fra Kymbo, Västergötland, er skarpsindigt af Torun Zachrisson blevet sat i forbindelse med Odin, de hængtes gud: De slappe nedadhængende arme og fødder med tåspidserne pegende nedad synes at gengive kropsholdningen hos en hængt, hvor halsringen giver mindelser om en løkke om halsen..$^{51}$ At der er tale om guden selv, og dermed et lille idol eller en amulet, som Zachrisson mener, er dog efter min opfattelse ikke givet; der kan lige så vel være tale om en afbildning af et rituelt subjekt, en dyrker af Odin.

I forlængelse af Zachrisson kan man hævde, at mange detaljer ved både figuriner og guldgubber synes at afspejle fysiologiske konsekvenser af hængning: Skuldrene synes i flere tilfælde at være sænkede; armene og benene er i flere tilfælde ikke strakte, men bøjede i leddene, hvilket kan ses som en gengivelse af fremskredet rigor mortis på den ophængte krop. ${ }^{52}$

Der er også grund til at fremhæve de træk af initiationsceremoniel, der knyttes til Odinkulten. Centralt i initiationsritualer verden over er den symbolske død og tilbagevenden til livet, der også afspejles i myten om Odins selvofring ved hængning, som den gengives i eddadigtet Den højes tale, hvor han hænger ni døgn uden mad og drikke i træet, såret med spyd, hvorved han opnår indsigt i skjult visdom. ${ }^{53}$ Visse antydninger i norrøn litteratur lader formode, 

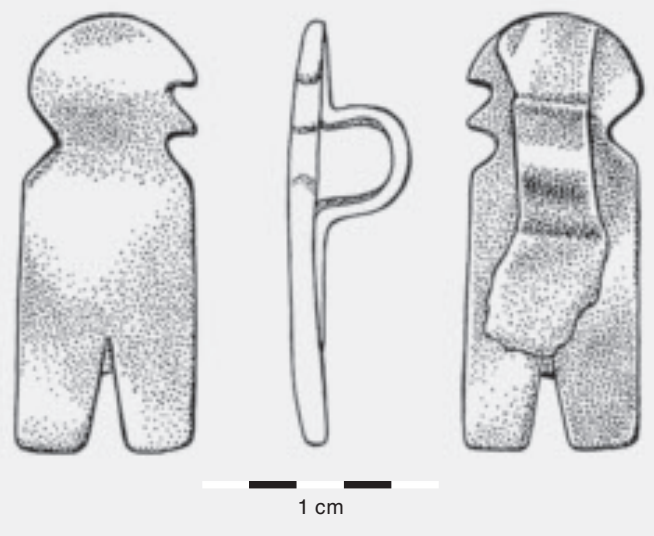

Fig. 3. Guldgubbe med øsken på bagside. Kville, Hög Edsten, Bohuslän. - Historiska museet.

at der har eksisteret lignende ritualer, hvor der har været brugt forskellige ikke-dødelige remedier eller attrapper til at imitere Odins selvofring. Således stilles Kong Vikar på en træstub, en tynd løkke af kalvetarme lægges om hans hals og fæstnes til en tynd kvist $\mathrm{i}$ træet over ham, mens Starkad forretter dette skindoffer ved at stikke til Vikar med et tagrør, i stedet for et spyd, med ordene: "nu giver jeg dig til Odin!" 54

Der er flere eksempler på, at gruppen af nøgne guldgubber, der synes bedst at gengive hængte, rent faktisk har været beregnet til ophængning. Tre gubber fra Kville, Hög-Edsten, Bohuslän, har monteret øskener på ryggen (fig. 3), en gubbe fra Nørre Hvam, nær Holstebro, har et gennemboret øje egnet til ophængning, mens løse øskener kendes fra ældre guldgubbefund fra Bornholm. ${ }^{55}$ Senere fund fra Bornholm af gubber med øsken udgøres af et fund fra Sorte Muld med øsken monteret på ryggen samt en gubbe fra Guldhullet med en kraftig øsken monteret på hovedet. ${ }^{56}$ Det er også muligt, at de mange eksempler blandt de nøgne gubber med en guldtråd eller strimmel bukket omkring halsen har kunnet ophænges med en tynd tråd bundet til disse ringe. Også de skarpt markerede hoveder med kraftigt fremspringende kæbepartier og markerede baghoveder har formentlig gjort det muligt at ophænge mange af dem i en tråd med en løkke om halsen.

Ind i denne sammenhæng passer også de indhak ved skuldrene, som René Laursen har bemærket ved guldfigurinen fra Guldhullet, der som nævnt kan tolkes, som om figuren skal fremstille en krop med indsnørede arme. Jeg vil mene, der kan være tale om en realistisk gengivelse af, hvordan en ikke-dødelig ophængning i forbindelse med Odin-kulten kan have foregået: Armene bundet 
stramt ind til siderne med kroppen ophængt fra bagsiden - ligesom guldgubberne med øskener monteret på ryggen - i en imitation af Odins pinsler på Yggdrasil. Hvis der også har været tale om en fasteperiode som del af ritualet, som det er beskrevet i Den højes tale, så kan det forklare, hvorfor denne lille kvindefigur ser så udsultet ud, med tydelige ryghvirvler. Som Margrethe Watt har bemærket, så er nøjagtige paralleller til gestussen med de indadvendte håndflader på maven at finde på de mandlige figuriner fra Lunda, der også i øvrige detaljer er nære paralleller til guldkvinden fra Guldhullet. Gestussen genfindes på et bæltespænde fra La Balme, Schweitz, fra 6. eller 7. århundrede, med det kristne motiv med Herrens indtog i Jerusalem, hvor tilskuerne har placeret hænderne i samme positur. Gestussen kan i den kontekst tolkes som en adorant-gestus og udtryk for ydmyghed og ærefrygt i nærheden af en guddom. ${ }^{57}$ Ved figurinen fra Guldhullet kan man formode, at der er tale om noget lignende, blot her til en anden guddoms ære, nemlig om indvielse i den nordiske døds- og visdomsguds mysterier.

\section{De trolde-lignende guldgubber fra Guldhullet}

En lille gruppe guldgubber, formet i en kombination af stemplede ansigter og udskårne lemmer og hårstrå, er blevet omtalt som "trolde-", "orangutang-" eller "gorilla-lignende", da de har det tilfældes, at deres ansigter er placeret $\mathrm{i}$ kroppen, eller blot rager en smule op over skulderhøjde (fig. 4). Seks figurer med groft udførte lemmer er stempelidentiske med et ansigt på torsoen, med hvad der ligner en bred næse og et tvedelt hageskæg. En enkelt af disse har angivet hårstrå i skulderhøjde og over ansigtet (fig. 4a). Tre andre figurer har mere detaljeret udformede lemmer med tydelige fingre og tæer, hvor armene holdes nedadvendt langs kroppen med udadvendte håndflader, eller foldes ind over kroppen. Dertil har de detaljeret udformede ansigter, hvor hovedet rager lidt op over skulderhøjde. Kaul mener, at der på to af disse figurer ses antydning af en hals. På den ene er denne stump dog, ud over et par indskårne hårstrå, forsynet med en indstemplet frisure, der minder om noget, der også kendes blandt brakteaterne, og her tydeligvis skal gengive hovedhår (fig. 4b). Formentlig er der altså blot tale om det øverste af det nedsunkne hoved eller hovedhår, der rager op over skulderhøjde, som det også tydeligt ses angivet på en af disse figurer ved indridsede hårstrå langs hele den del af hovedet, der rager op over skulderhøjde (fig. 4c). En sidste meget firskåren figur har et ansigt under skulderhøjde, tydeligt angivne lemmer og hårstrå angivet over ansigtet langs hele skulderpartiet (fig. 4 d)..$^{58}$ 


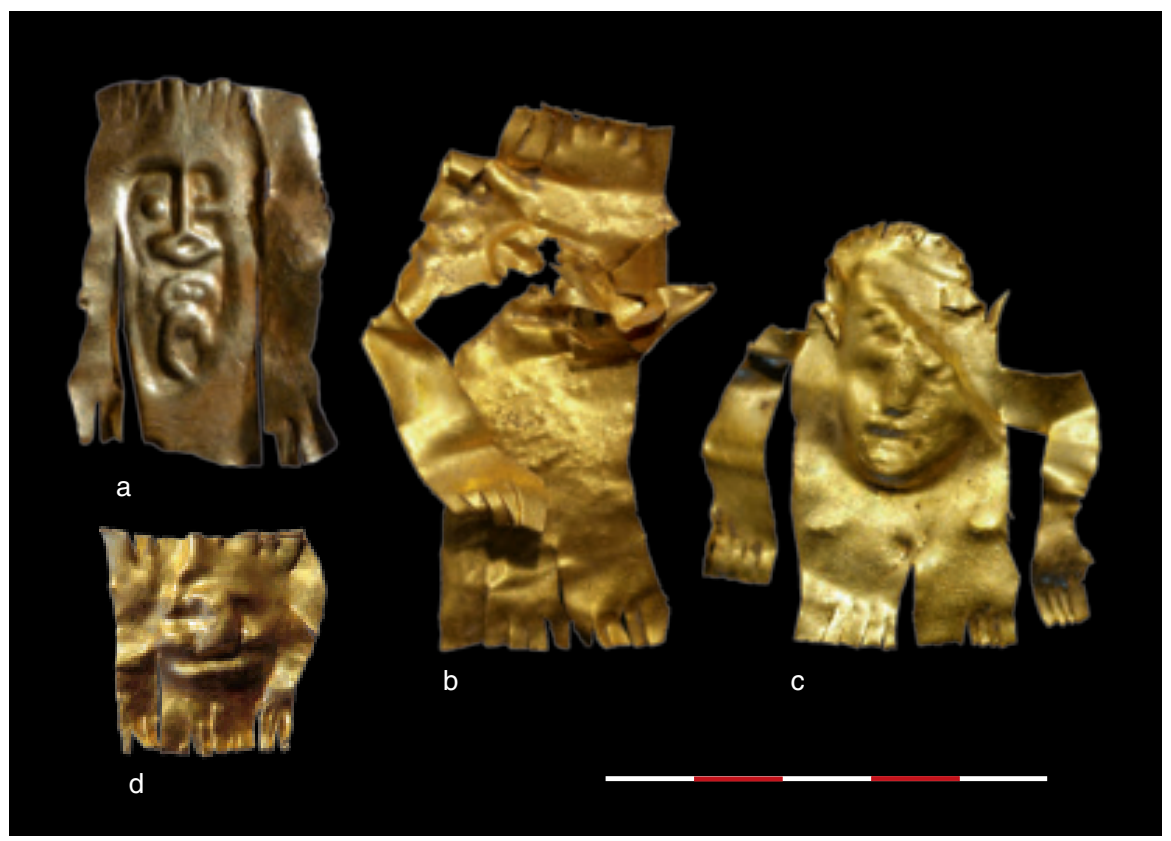

Fig. 4. Guldgubber med ansigt i kroppen, Gulhullet, Smørenge. Bornholm. - Foto: René Laursen, Bornholms Museum.

\section{Troldtøj og tordenvejr}

Der kan udtrykkes berettiget tvivl om, hvor gammel eller oprindelig Odins rolle som jæger af troldeagtige kvinder i nyere tids folklore er. Modsat hersker der ikke megen tvivl om, at Tor som ivrig jæger af troldtøj, eller blot troldtøjets velkendte frygt for tordenvejr, i skandinavisk folklore fra nyere tid bygger på en tradition, der går tilbage til førkristen tid. Udover at kæmpe mod jætter er det især at smadre trolde, der optager Tor ifølge de ældste kilder. I disse kilder er det påfaldende, at troldene - når dette angives - altid er af hunkøn. I de yngre kilder er dette forhold mindre udtalt, men dog er det almindeligt, at der er tale om kvindeligt troldtøj, på Sveriges fastland gerne skogsrå, på Gotland den såkaldte Torspjäsku. ${ }^{59}$ Der er i flere sagn også tale om tydelig motivudveksling mellem kvindejagtsagnet og troldenes tordenfrygt. Som vi har set, er de lange hængende bryster dertil et generisk træk ved forskellige overnaturlige kvinder, og motivet forekommer ofte i nyere folkesagn om trolde, der fældes af lynet. Kaul nævner selv eksempler på dette, og flere kan nævnes, men han drager ikke heraf den nærliggende slutning, at figurer som Slattenlangpat ikke er specielt tilknyttet kvindejagtsagnet eller Odin-figuren, og at der ikke er nogen skarp opdeling mellem den vilde jægers og tordengudens bytte. ${ }^{60}$ 


\section{Troldes udseende}

Spørgsmålet om troldenes udseende er naturligvis vigtig, hvis man vil forsøge at sammenligne disse væsner med de meget specifikt udseende guldgubber med nedsunket ansigt. Derfor er det frustrerende, at nyere folklore tillægger troldene evne til at omskabe sig til f.eks. dyr eller garnnøgler, eller simpelthen være usynlige. Visse historiske udviklingstræk og regionale forskelle i troldenes udseende står dog fast. Som nævnt, hvis man skal orientere sig efter de ældste vestnordiske kilder, var troldene i førkristen tid udelukkende kvindelige væsner, der ikke beskrives detaljeret, dog som tydeligt monstrøse. ${ }^{61}$ Især den norske troldetradition fra nyere tid synes at have beholdt den monstrøse størrelse og det groteske ydre, mens de østnordiske trolde som regel er af menneske- eller dværgstørrelse og sjældnere tillægges groteske træk. I Sverige er betegnelsen "troll" almindelig, i Danmark forekommer betegnelsen "trold" sjældnere og bruges i flæng med den mere almindelige betegnelse "bjærgfolk". I nyere tids skandinaviske folklore bruges begrebet trold ofte som samlebegreb for alle menneskelignende overnaturlige væsner. I moderne tid er vores opfattelse af trolde ikke mindst skabt af illustratorer og kunstnere som Theodor Kittelsen og John Bauer eller gennem populære figurer som Gjøl-trolden, Krølle Bølle og Skærmtrolden Hugo. ${ }^{62}$ En vigtig rolle har også kristendommens djævletro spillet for udformningen af troldenes ydre, hvilket vi skal vende tilbage til.

\section{Trollernes trold}

Troldenes udseende i norrøne kilder eller nyere tids folklore efterlader således et betydeligt spillerum for fantasien, men myter, sagaer, sagn og eventyr kender på den anden side tilsyneladende ikke noget til trolde med ansigt i maven. Kaul koncentrerer sig da også om en mere specifik, og unik, tradition for afbildning af trolde, nemlig trolden i adelsslægten Trolles våbenskjold, der er halshugget, men med et ekstra ansigt placeret på bugen. Trolleslægten brugte allerede fra 1411 på deres sigil billedet af en trold, fra $1444 \mathrm{i}$ den nu almindelige version med afhugget hoved og ansigt på bugen. ${ }^{63}$ Anders Olsen gengiver en mere detaljeret udgave af Trollernes våben i et træsnit fra 1560 (fig. 5). Over skjoldet ses det afhuggede hoved, med horn i panden, spidse ører og udspilet tunge. På selve skjoldet ses en lodden figur med halsstump, en lang kohale, der holdes i den ene klobesatte hånd, på overkroppen ses hængende bryster, og på underkroppen et grimmaserende ansigt, mens fødderne er formet som spaltede klove.

Trollernes våben henviser til deres slægtssagn om forfaderen Herve Ulfs møde med troldene i Trolleklippa på vej til gudstjeneste julenat i Voxtorp kirke i Småland. Der er tale om en version af sagnet om det stjålne drikkebæger, 


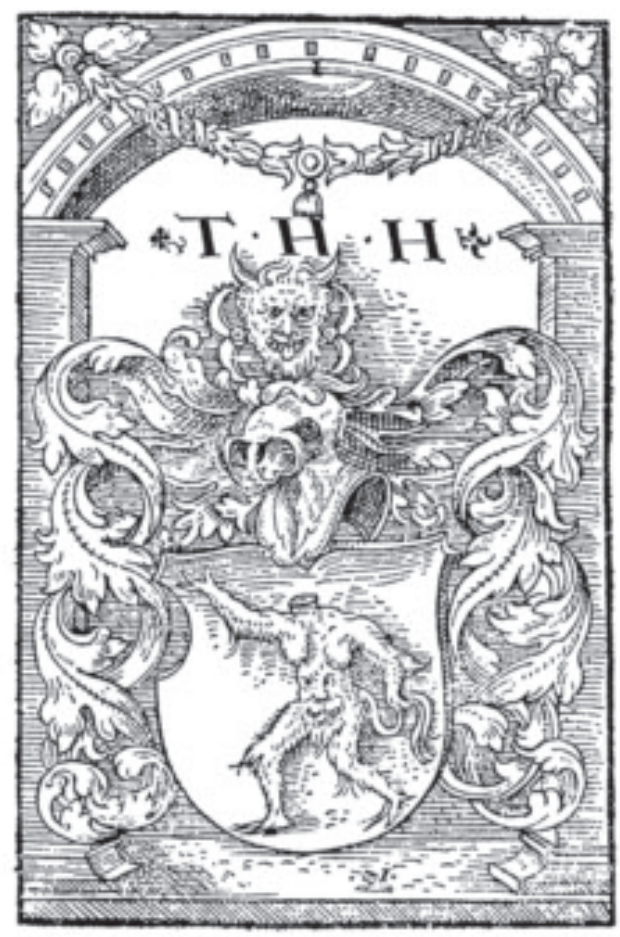

Fig. 5. Træsnit af Trollernes våbenskjold i Anders Olsens regnebog fra 1560. Spejlvendt i forhold til original. - Efter Achen 1965, s. 17.

der er et almindeligt vandresagn i Skandinavien. Trollernes udgave kendes tilbage fra Biskop Petrus Jonæ Angermannus' ligprædiken over Anna Trolle i 1617 , trykt 1620 :

"[da] upsatte Satan sigh medh en hoop aff sine Andar, kom emoot honom lika som en brudaferdh wiliandes samma Gudztienst hindra. Då stelte Satan en j Jungfrus lichnelse fram, som kom medh itt dryckehorn och drak Herren till”. Videre, efter at ridderen har hugget hovedet af djævlen i kvindeskikkelse, og undsluppet, fortsætter prædiken:

“...när han ifrå Gudztienesten tillbaka kom fanns samma Jungfrus licknelse liggiandes på wägen medh sådan skapnad som Trollers wapn ännu j många uthugna stenar fins." ${ }^{64}$

Kaul mener, at man i denne kilde finder beskrevet "den hovedløse trold med hoved i maven i en kompleks fortælling". ${ }^{65}$ Biskoppens kommentar betyder dog ikke nødvendigvis, at troldekroppen ifølge sagnet blev fundet med et ansigt i maven. Dette billedtræk er nemlig kun én variant af Trollernes våben, hvorimod en trold uden hoveder, hverken på hals eller bug, er det almindeligste, og som sådan forekommer på de fleste af slægtens ligsten fra 1500- og 1600-tallet i Danmark, ligesom det så vidt vides er den eneste kendte type i Sverige. ${ }^{66}$ Formentlig 
mener biskoppen derfor blot, at troldekroppen blev fundet med afhugget hoved. Endnu en tidlig gengivelse af sagnet af antikvarikeren Petter Rudebeck fra 1690 giver en mere detaljeret beskrivelse af troldens halshuggede lig:

“...och då han kom til samma ställe igien der han Jungfruhufwudet afhuggit hade, si då låg der et wederstyggeligit och ledt tråll, med stort hufvud långa åsneöron och illa grinande mun, med Klor på händer och fötter, och en lång rumpa...”67

Her beskrives troldehovedet nøje, men uden at nævne noget usædvanligt ved placeringen. At trolden i sagnet havde et hoved i maven, findes der således ikke tekstuelt belæg for.

\section{Middelalderens djævlebilleder}

Hypotesen om, at varianten af Trolleslægtens trold med afhugget hoved og ansigt på bugen, der findes første gang i senmiddelalderen, skulle gå tilbage til yngre jernalders forestillinger om trolde, hvilket ses af guldgubberne med ansigtet placeret på torso, indeholder en afgørende metodisk brist. Der er et spring på ca. 1.000 år mellem de sammenlignede billedgrupper, og ved at sammenligne dem direkte, uden først at undersøge deres historiske og kulturelle miljø separat, er der stor risiko for at overse vigtige forhold. Med andre ord risikerer man at fokusere for meget på overfladiske ligheder uden at få øje på forskelle og muligheden for separate oprindelser for de forskellige motiver. Jeg mener, at dette er tilfældet her, og at hvis man undersøger Trollernes troldebillede i dets egen tid og miljø, så ser man, at dette billede er helt afhængig af høj- og senmiddelalderens tradition for afbildninger af djæevle.

I det 12. århundrede begynder kunstnerne bevidst at gribe tilbage til antikkens afbildninger af forskellige guddomme og andre overnaturlige væsner - ikke mindst Pan og satyrerne - for at afbilde Helvedes urene ånder, hvilket gav udmærket mening ud fra den kristne devise om, at al fortidens hedenskab jo var djæevelskab. Herfra stammer det klassiske billede af en djævel, som folk ofte stadig har for sig: Ansigt med horn, spidse ører og gedeskæg, lodden krop, hale, bukkelår og hove.$^{68}$ Fra det 13. århundrede bliver det almindeligt at give djevlene endnu et ansigt - ofte placeret på maven, andre gange i skridtet eller på bagdelen, eller endda give dem flere hoveder, på albue, knæ, kønsdele, bryster osv. Også her kommer inspirationen fra antikke forbilleder. Den passende grimasse fandt man i antikkens gorgon-masker, hvor det arketypiske eksempel befinder sig på Athenas aegis. Det var dette gorgoneion, slynget over Athenas torso eller placeret på hendes skjold, der ifølge kunsthistorikeren Oswald A. Erich af middelalderens kunstnere ved en misforståelse blev opfattet som en 
integreret del af kroppen. At dette grimasserende ansigt blev en fast bestanddel af djæevlekroppen i løbet af senmiddelalderen skyldes også, at det passede ind som en understregning af djæevlenes nedrige natur, hvor kroppens nedre regioner og drifter stod i højsæde og nærmest ses at leve sit eget liv i kraft af disse grimasserende ansigter. ${ }^{69}$ Andre typiske træk i middelalderens djævleflok er rovfuglekløer, svømmehud, spilende tunger, lange næser, og af og til selvfølgelig også de ikoniske flagermusvinger, foruden hængende bryster. ${ }^{70}$

Som det ses på Anders Olsens træsnit, har Trollernes trold hængende bryster. Dette er også tilfældet for Abel Schröders karyatide under prædikestolen i Vejlø Kirke fra 1668, der ofte identificeres som den lokale sagnfigur Slattenlangpat. ${ }^{71}$ Den ledsagende latinske indskrift benævner hende "dæmon" og refererer derefter til "insignia Trolia". ${ }^{72}$ De lange bryster er som nævnt et typisk træk for alskens kvindeligt troldtøj i nyere folklore, men de hængende bryster ses som nævnt også som et typisk træk på ellers androgyne eller kønsløse djævlekroppe i senmiddelalderens og renæssancens kunst. Et berømt eksempel fra Det Sixtinske Kapel er Boticellis udgave af Jesu fristelser (1481), hvor Den Onde til sidst fordrives, smider sin kutte og afslører sin djevelske krop med hale, satyrlår, rovfuglekløer og slappe "gammelkonebryster" (fig. 6). ${ }^{73}$ Hængebrysterne signalerer i middelalderens moralske og æstetiske univers det modsatte af de idealiserede små og faste ungpigebryster, der udtrykker moralsk integritet og erotisk attråværdighed, men samtidig jomfruelighed ifølge datidens litteratur, lægevidenskab og kunst. ${ }^{74}$ At formode en vekselvirkning med folketroens troldkællinger og deres attributter er på dette punkt oplagt.

Når trolden på Trollernes våbenskjold således ses som lodden, med horn, hale, spidse ører, hængebryster, kløer og ansigt på bugen, så er der tale om en udvikling, hvor et væsen fra den nordiske folketro med rødder tilbage i førkristen

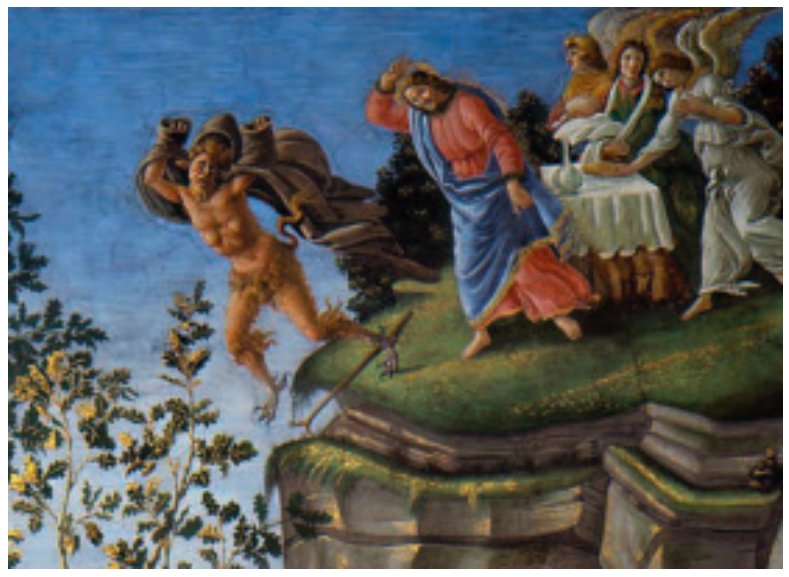

Fig. 6. Detalje fra det Sixtinske Kapel, Vatikanet, af Botticellis Jesu fristelser fra 1481. - Wikimedia Commons. 
tid er smeltet sammen med det visuelle udtryk, som er udviklet i en europæisk, kristen, højmiddelalderlig tradition, der igen trækker på Romerrigets førkristne billedkonventioner. Djævletypen med ansigt på maven var allestedsnærværende og let tilgængelig for kunstnere bag Trollernes våbenskjold, nemlig i kirkekunst såsom 1400- og 1500-tallets kalkmalerier. At al folketro blev betragtet som hedenskab af de toneangivende gejstlige lag i samfundet har langt hen ad vejen gjort de indfødte trolde og den kristne kulturs djævlepak til en og samme ting. Trollernes trold, med ansigt på bugen, har således efter min mening sin specifikke oprindelse i den kristne middelalders billedkonventioner og ikke i en indfødt forestillingsverden med kontinuitet tilbage til yngre jernalder.

\section{Et alternativ: Guldgubberne som blemmyer}

En vigtig forskel - der i forbifarten kan synes som blot en detalje - mellem Trolleslægtens trold og de omdiskuterede guldgubber, er, at deres ansigter sidder forskellige steder på kroppen. Placeringen af ansigtet hos trolden kan beskrives som på maven, bugen, eller underkroppen. Et træk der, som beskrevet ovenfor, stammer fra middelalderens djævlebilleder. Guldgubberne derimod har deres ansigt placeret på torso, brystet, eller overkroppen, i flere tilfælde hvor toppen af hovedet eller blot hovedhåret rager op over skulderhøjde. Dette leder tankerne andre steder hen end mod djæevle med bugansigt.

I en kommentar til Kauls tolkning på Videnskab.dk har antropolog Lars Christian Kofoed Rømer foreslået, at man alternativt kunne undersøge, om der måtte være en sammenhæng med forestillinger omkring stammer af hovedløse mennesker, som kendes tilbage fra antikke kilder. ${ }^{75}$ Der tænkes givetvis her på de såkaldte "blemmyae" eller "akephaloi", der første gang optræder hos Herodot. Ifølge beskrivelserne havde de øjne og mund på brystet eller ved skuldrene. I antikken og middelalderen henlægges deres habitat til Nordafrika. I senmiddelalderen bliver de et yndet billedtema, og på diverse verdenskort placeres de efterhånden også i andre af verdens udkanter, i Asien eller Indien. ${ }^{76}$ Alternativet, at den nye type guldgubbe fra Guldhullet forestiller blemmyer, har den fordel i forhold til Kauls hypotese, at ansigtet på gulgubberne følger placeringen anført i kilderne fra antikken, der i dette tilfælde rækker langt nok tilbage til at være relevant for tiden omkring år 500 e.Kr., i modsætning til det djæevelske bugansigt, der, som vi har set, har sine forudsætninger i højmiddelalderen. ${ }^{77}$ Afbildninger af blemmyer er dog tilsyneladende ret sjældne i den tidlige middelalder. Der kan dog henvises til en tidlig afbildning i det såkaldte Beowulf-manuskript fra omkring 1000 e.Kr., der ud over teksten til Beowulf bl.a. indeholder en angelsaksisk oversættelse af et værk om Orientens 


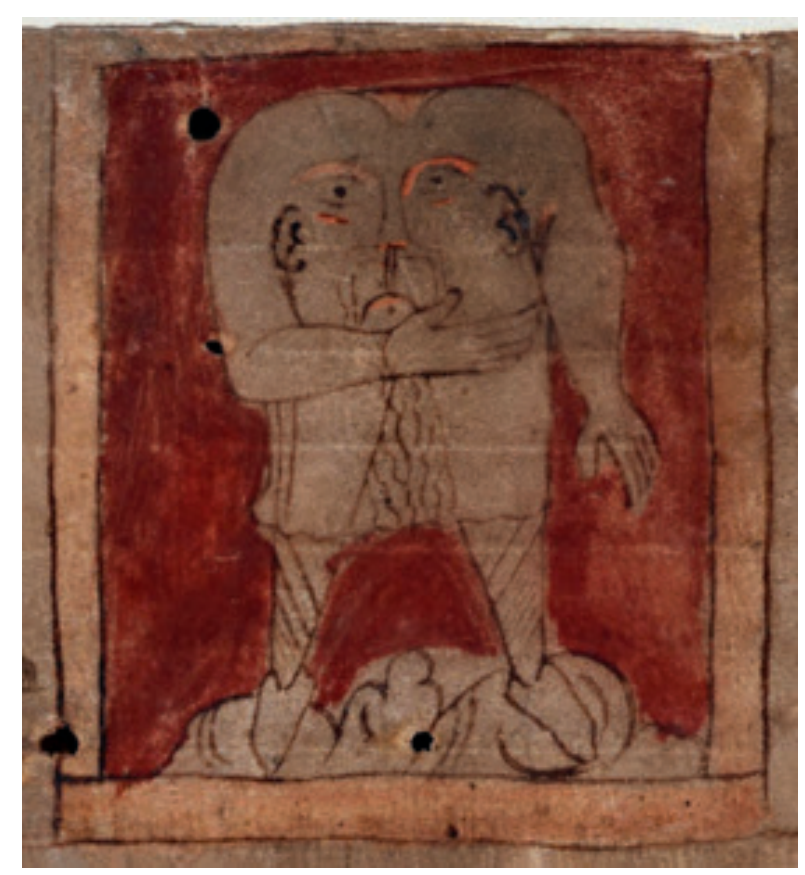

Fig. 7. Blemmy fra

Wonders of the East, Beowulf-manuskriptet, ca. 975-1000 e.Kr. Cotton MS Vitellius A XV, f102v. The British Library.

eksotiske væsner og monstre (fig. 7). ${ }^{78}$ Muligvis er de bornholmske guldgubber de ældste gengivelser af de hovedløse mænd, hvilket er en mindst lige så spændende mulighed, som at der skulle være tale om trolde.

\section{Konklusion}

Det har ikke været formålet med denne kritik generelt at afvise, at nyere tids folkesagn fra Danmark og Sverige kan have rødder tilbage til eller indeholde elementer af forestillinger, der går tilbage til tiden før kristendommens indførelse i Norden. At tordenguden stadig jagede trolde i Småland ifølge kilder fra 1800-tallet, er jo et godt eksempel på, at dette kan være tilfældet. Men derfra og til at se en vrimmel af halvglemte guder fra nordisk mytologi bag hvert væsen fra nyere tids sagnverden er en anden sag. Folkesagnene består i høj grad af internationalt stof, der er tilkommet i løbet af middelalderen og efterreformatorisk tid, og er som sådan opstået ud fra eller formet af den tids herskende forestillingsverden, ikke mindst kristendommen. Der er i samme tidsrum sket betydelige forandringer inden for ikonografi og kunst. En direkte sammenligning mellem forhistorisk billedmateriale og materiale fra senmiddelalder og nyere tid er derfor metodisk set at fraråde. Det er nødvendigt først at undersøge de enkelte elementer i hver deres historiske miljø - såsom at undersøge, om 
figuren med hoved i maven har paralleller i samtidigt materiale - før man søger at bruge dem til at forklare et billede, der er 1.000 år ældre. Hvis der findes paralleller i samtidigt materiale, må man undersøge denne traditions opkomst og vurdere, om der er nogen forbindelse til det ældre materiale, eller om der blot er tale om overfladiske ligheder med forskellige historiske oprindelser.

Løsninger af gåderne om billedindholdet i den yngre jernalders figurkunst kræver tværfaglighed, og tolkernes specialisering inden for afgrænsede fagretninger er derfor et problem. Af den grund må det også være tilladt at forsøge at arbejde med tilstødende fags materiale og metoder og udkaste dristige hypoteser, som Kaul har gjort. Ellers kommer vi ingen vegne. Hypoteser er til for at blive efterprøvet, og her er kritikeren af en tværfaglig hypotese i samme båd som fremsætteren - de er begge amatører på dybt vand, langt fra deres snævre faglighed. Jeg mener dog, at Kauls metodiske valg er problematisk. Jeg mener også, at man bør overveje alternative tolkninger af de omtalte guldfigurer. Om hans forståelse af Nordens nyere folkesagn stemmer med etnologernes må være op til dem at vurdere endegyldigt, men ud fra mit synspunkt er der grund til skepsis på vigtige punkter. At der skulle være de angivne sammenhænge med jernalderens guldfigurer, finder jeg ikke er tilfældet.

\section{NOTER}

1. Kaul 2018a og 2018b. Artiklerne er ikke længere tilgængelige på Videnskab.dk, hvor der dog kan læses følgende baggrundsartikler: Persson 2018a; Persson 2018b. Om baggrunden for hypoteserne og lanceringen af artiklerne kan læses på Nationalmuseets Facebookside: https://www.facebook.com/DanmarksogMiddelhavslandenesOldtid/posts/nu-kom-den-artiklen-om-slattenlangpat-af-seniorforsker-flemming-kaulnetop-udkomm/2159318877473856/ (tilgået 22-05-2019) og https:/www.facebook. com/DanmarksogMiddelhavslandenesOldtid/posts/guldgubber-og-guldhulletseniorforsker-dr-phil-flemming-kaul-p \%C3\%A5-bornholm-presse-o/2325669264172149/ (tilgået 22-05-2010).

2. Kaul 2018a, s. 25.

3. Laursen 2013.

4. Kaul 2018a s. 14.

5. Kaul 2018a, s. 29.

6. Laursen 2013, s. 14; Kaul ibid.

7. For oversigter over sagnets udbredelse, forskellige delmotiver, samt forskningshistorik, se: Röhrich 1965; Röhrich 1967; Campbell \& Nyman 1976.

8. Mannhardt 1875, s. 445; Golther 1895, s. 288. Myten om Freya og Óðr, se Sturluson 2013, Gylfis Blændværk kap. 35.

9. Originaltekst i Röhrich 1967, s. 5f.; engelsk oversættelse og kommentar i Lecouteux 2011, s. $59 f$.

10. Originaltekst i Röhrich 1967, s. 6f.; engelsk oversættelse og kommentar i Lecouteux 2011, s. 57 f. 
11. Campbell \& Nyman 1976, s. 49f.

12. Kaul 2018a, s. 26.

13. Den svenske folkemindeforsker Bengt af Klintberg sammenfatter forskningsstanden således, 1972, s. 20: "Frågan om det finns en obruten tradition från asaguden Oden fram till den yngre folktrons jägare har inte kunnet besvaras; man har nog rätt att vara tvivlande på den punkten.”

14. Om Odin i senmiddelalderens og nyere tids trolddomsforestillinger, se: Mitchell 2009. Om Odins rolle i nyere folketro, se: de Vries 1931.

15. Kristensen 1892-1901: II, C 1-4; Olrik 1901; Campbell \& Nyman 1976, s. $49 \mathrm{ff}$.

16. Se Lecouteux 2011 for en opregning af navnene på den vilde jagt og jagtens leder, s. 258ff. Se også Rörich 1967, s. 403f. og Campbell \& Nyman 1976, s. 47ff. for jægerens forskellige navne.

17. Grimm 1875 [1835]: II, s. 870ff.

18. Hö̈ler 1934.

19. Lecouteux 2011, s. 202ff.; Hutton 2014.

20. Kaul 2018a, s. 26f.

21. Röhrich 1965, s. 409f., 412f.; Olrik 1901, s. 150.

22. Kristensen 1892-1901: I, nr. 27, 215, 457, 773, 774, 775; ibid. 1892-1901: II, A: nr. 42, 117, 119, 133; ibid. 1928-1939: I, nr. 276, 391, 567, 570, 573, 574; ibid. 19281939: II, nr. 4, 5, 52.

23. Machál 1918, s. 264.

24. Zingerle 1891, s. 111; Beitl 2007 [1933], s. 41ff.

25. Campbell 1900, s. 42 f.

26. Röhrich 1965, s. 413. De lange bryster, der kan kastes over skuldrene, som et karakteristikum for kvindelige sagnvæsner, har, ud over de her nævnte eksempler fra europæisk folklore, en nærmest global udstrækning. Motivet kendes fra beskrivelser af Asiens vilde folk, hvor yetien nok er den bedst kendte, jf. Forth 2008, s. 266ff., s. 277ff., og fra Jamaicansk folklore i forbindelse med figuren Buppy Susan, jf. Leach 1963, s. 71.

27. Holbek \& Piø 1967, s. 127.

28. Kristensen 1892-1901: II, A: nr. 4, 42, 117, 119, 133; ibid. 1928-1939: II, nr. 52.

29. Granberg 1935, s. 25ff.; Holbek \& Piø 1967, s. $131 \mathrm{ff}$.

30. Kristensen 1928-1939: II, nr. 5.

31. Kristensen 1892-1901: II, nr. 92.

32. Granberg 1935, s. 251ff. Der kan dog nævnes en enkelt undtagelse, som synes at være undsluppet Granberg: I en optegnelse fra 1932 fra folkemindearkivet i Göteborg (Acc.nr. IFGH02771) fortælles om en hyrdes natlige møde med Skt. Thomas, der jager og nedlægger en kvinde, der, slynget over sadlen, ses at have en hul ryg. Dette er det eneste eksempel på et kvindeligt jagtbytte med hul ryg i de 87 digitaliserede varianter af "Den vilde jakten", som findes på sägenkartet, der drives af Instituttet för språk och folkminnen: http://www.sprakochfolkminnen.se/om-oss/kartor/ sagenkartan.html\#/record/1605 (tilgået 22-05-2019).

33 https://www.naestved.dk/Kommunen/MaerkNaestved/DownloadMaerkNaestved/ HistorierneBagLogoet/Slattenpatten.aspx (tilgået 22-05-2019); oplysningen findes også på Wikipedia, med et nu dødt link: https://da.wikipedia.org/wiki/Slattenpatten (tilgået 22-05-2019). 
34. Schmidt 1932, s. 11. Stenen angives ikke længere at kunne lokaliseres. Gennem Præsteskoven løber Møllebækken, med udløb i Mølleåen, der igen har udløb i Fladsåen. Der er således tale om et andet system end Susåen.

35. Kristensen 1892-1901: II, C: nr. 82.

36. Rolf Krakes saga 2016, kap. 23.

37. Mannhardt 1875, s. 147.

38. Tybjerg 2010, s. $58 \mathrm{ff}$.

39. Olrik \& Ellekilde 1926-1951:1, s. 401ff. Hypotesen modsiges desuden af resultaterne i Granbergs afhandling om skogsrået, ibid.

40. Leclercq 1975; Weir \& Jerman 1986, s. 58ff.

41. Odenius 1961; Luyster 2001.

42. Mackeprang 1941, s. 61, s. 80ff.; Odenius 1961, s. 6f.

43. Kaul 2018a, s. 27.

44. Andersson et al. 2004, s. 62; Laursen 2007, s. 47.

45. Larsson 2001, fig. 5; Watt 2008, s. 42 midt nederste række, s. 49, midt nederste række, s. 51, øverste to rækker.

46. Køng: Mackeprang 1935, s 236f.; Thrane 2005, s. 34, 36, der dog mener, der er tale om en "gourmetvom". Lunda: Andersson et al. 2004.

47. "tempelpenge": Watt 1991, s. 99; jf. Watt 2008, s. 52f.; Baastrup 2015.

48. Brøndsted 1954, s. 79; Voss 1990, s. 138. Som påpeget af Thrane 2005, s. 34, så er de fleste af de importerede romerske gudestatuetter dog påklædte, i kontrast til de nordiske pendanter.

49. Hutton 2003.

50. Ibn Fadlan 1981, kap. 91.

51. Zachrisson 2003.

52. Rigor mortis hos hængte og deres udtryk i yngre jernalders ikonografi i sammenhæng med nordisk førkristen religion har jeg behandlet i mit speciale: Laursen 2005, s. 29ff. Jf. Fischer 2007, s. $174 \mathrm{ff}$.

53. Den højes tale, str. 138-141.

54. Standardværket om initiationssymbolik i nordisk førkristen religion er Schjødt 2008; om Odins selvhængning, se denne s. 173ff. Gøtreks saga 2017, kap. 7: I samme øjeblik, Starkad ytrer disse ord, forvandles tagrøret dog til et spyd, der gennemborer kongen, tarmene forvandles til et kraftigt reb, og træet over kongen skyder til vejrs, således at ceremonien trods alt ender som et dødeligt offer til Odin.

55. Mackeprang 1943, s. 45.

56. Se Watt 1992, fig. 10c; Laursen 2018, fig. 4.

57. Watt 2015, s. 180, s. $184 f$.

58. Laursen 2018; Nielsen \& Watt 2018. Med halsstump, se Kaul 2018b, s. 20, s. 22.

"Kalotformet frisure" eller "karsehår" på brakteaterne, se Axboe 2007, s. $127 f$.

59. For den norrøne litteratur, se Arnold 2005, s. 121f., n.26. For oversigt over motivet i nyere tids folklore, se Schön 2004, 211ff. Om skogsrået som offer for tordenen, se Granberg 1935, s. 202ff.

60. Kaul 2018b, s. 22. For andre eksempler på langbrystet troldtøjs frygt for tordenvejr, se Olrik \& Ellekilde 1926-51:1 s. 447; Granberg 1935, s. 208. 
61. Monstrøs størrelse omtales således i Vølvens spådom str. 29, for det afkom som troldekvinden i Jernskoven føder i form af en ulv i troldeham, der skal sluge månen. I listen af troldenavne i nogle udgaver af Eddaen optræder en "Loddenfinger", hvilket tyder på en behåret fremtoning, jf. Lindow 2014, 14ff.

62. Et ældre standardværk om trolde er Hartmann 1936, et nyere er Lindow 2014, også med en gennemgang af trolde i moderne kunst, litteratur, marketing og popkultur.

63. Achen 1965, s. 16; jf. Lövkrona 1988 s. 55f.

64. Om sagntypen "Det bortrøvede drikkekar", se Lövkrona 1982. Om Trollernes slægtssagn specifikt, se Lövkrona 1988. Citat fra Lövkrona 1982, Bilag 21.

65. Kaul 2018b, 24.

66. Achen 1965, s. 17. At varianten med afhugget hoved og ansigt på bugen i dag er blevet kanonisk gennem brugen i stamtavlen over Trolle-slægten i Danmarks Adels Årbog 1891, som er inspireret af Anders Olsens træsnit fra 1560, og gennem kostskolen Herlufholms brug af samme variant som logo, er en anden sag. Varianten findes også på Trollernes epitafium i Roskilde Domkirke samt som atlant under prædikestolen i Gavnø slotskapel, begge som træskærearbejder og fra tiden efter biskop Angermannus' ligprædiken over Anna Trolle.

67. Lövkrona 1982, Bilag 22. På billedtavlen i Voxtorp kirke fra 1600-tallet, hvor sagnet er illustreret, ses den faldne troldekrop også uden ansigt i maven.

68. Erich 1931.

69. Erich 1931, s. 76f.; jf. Obrist 1976.

70. Erich 1931; se også Nyborg 1978, med mange illustrationer.

71. I en variant af kvindejagtsagnet refererer informanten direkte til figuren under prædikestolen i Vejlø Kirke, for at forklare hvilket væsen, der jages. Her kaldes hun dog for en “Gjødemo'r”, jf. Kristensen 1928-1939: II, C: nr. 66.

72. Danmarks Kirker 1933-35, VI: 2, s. 758 med latinsk tekst og oversættelse. I vestnordiske kilder optræder benævnelsen "troll" som synonym med ord for djævel, i gammelsvenske oversættelser af religiøs litteratur er det synonym med latinsk "daemon", ligesom ordparret "troll og djevler" er en fast vending, se Kulturhistorisk leksikon for nordisk middelalder, opslag: "troll".

73. "Bei der dritten dieser Szenen enflieht der Böse, dabei öffnet sich die Kutte und läßt einer scheußlichen Teufelskörper mit Satyrschenkeln, Raubtierkrallen und schlaffer Altweiberbrust sehen.": Erich 1931, s. 39.

74. Phillips 2018.

75. Persson 2018b.

76. For oversigt, se Holbek \& Piø 1967, s. 299f. og Wikipedias opslag om "Headless men": https://en.wikipedia.org/wiki/Headless_men.

77. Achen 1965, s. 16, angiver kalkmaleriet af en akefal fra ca. 1500 i Råby Kirke som eksempel på en hovedløs djævel, hvilket efter min mening er forkert og svært at forveksle med middelalderens djævletradition. Samme idé har Lövkrona 1988, s. 62, der mener, at Trollernes trold med bugansigt har sin direkte forudsætning i fremstillinger af akefaler, hvilket på samme vis ikke er korrekt. Akefalerne udgør en adskilt tradition fra djævlefremstillingerne, hvor maven i underlivet symboliserer seksuelle synder og straffen derfor i Helvede, jf. Obrist 1976, mens akefalerne bruges som symbol på frådseri, som en art omvandrende mavesæk, jf. Holbek \& Piø 1967, s. 300; Nyborg 1978, s. 70f. og Mittman 2003. 
78. "Beowulf-manuskriptet", Cotton MS Vitellius AX, fra sidste kvartal af 10. århundrede, indeholder, ud over digtet Beowulf og en række andre tekster, værket Wonders of the East, en angelsaxisk oversættelse af den latinske tekst De Rebus in Oriente mirabilibus. For baggrund og oversættelse, se Fulk 2010.

\section{LITTERATUR}

Achen, Svend Tito 1965: Trolle-våbenet. Heraldisk tidsskrift bind 2, 11, s. 9-24.

Andersson, Gunnar et al. 2004: Att föra gudarnas talan. Stockholm.

Arnold, Martin 2005: Hvat er tröll nema pat? The Cultural History of the Troll. I: T.A. Shippey (ed.): The shadow-walkers. Jacob Grimm's mythology of the monstrous. Tempe, s. 111-155.

Axboe, Morten 2007: Brakteatstudier. København.

Baastrup, Maria Panum 2015: Invitation systems and identification in Late Iron Age southern Scandinavia? The gold foil figures from a new perspective. Danish Journal of Archaeology, vol. 4, s. 64-74.

Beitl, Richard 2007 [1933]: Untersuchungen zur Mythologie des Kindes. Münster.

Brøndsted, Johannes 1954: Guldhornene. En oversigt. København.

Campbell, John Gregorson 1900: Superstitions of the Highlands and Islands of Scotland. Glasgow.

Campbell, Åke \& Åsa Nyman 1976: Atlas över svensk folkkultur 2: Sägen, tro och högtidssed. Uddevalla.

Danmarks Kirker 1933-1935 VI, bind. 2. København.

Den højes tale 2018: Den poetiske Edda. Rolf Stavnem (overs.). København.

Erich, Oswald A. 1931: Die Darstellung des Teufels in der christlichen Kunst. Berlin.

Fischer, Christian 2007: Tollundmanden. Gaven til guderne. Mosefund fra Danmarks forhistorie. Højbjerg.

Forth, Gregory 2008: Images of the Wildman in Southeast Asia. An anthropological perspective. London \& New York.

Fulk, Robert Dennis 2010: The Beowulf Manuscript. Complete text and The Fight at Finnsburg. Cambridge.

Golther, Wolfgang 1895: Handbuch der germanischen Mythologie. Leipzig.

Granberg, Gunnar 1935: Skogsrået i yngre nordisk folktradition. Uppsala.

Grimm, Jacob 1844 [1835]: Deutsche Mythologie. Zweiter Band. Zweite Ausgabe. Göttingen.

Gøtreks saga 2017: Oldtidssagaerne, bind 3. Anette Lassen (red.). København.

Hartmann, Elisabeth 1936: Die Trollvorstellungen in den Sagen und Märchen der skandinavischen Völker. Stuttgart \& Berlin.

Holbek, Bengt \& Iørn Piø 1967: Fabeldyr og Sagnfolk. København.

Hutton, Ronald 2003: Witches, druids and King Arthur. London.

Hutton, Ronald 2014: The Wild Hunt and the Witches' Sabbath. Folklore, vol. 125, 2, s. $161-178$.

Höfler, Otto 1934: Kultische Geheimbünde der Germanen. Frankfurt am Main.

Ibn Fadlan 1981: Vikingerne ved Volga. Ibn Faḍlāns rejsebeskrivelse. Jørgen Bæk Simonsen (overs.). Højbjerg. 
Kaul, Flemming 2018a: Folkeminderne og arkæologien 1: Vandgudinden Slattenlangpat. Skalk nr. 4, s. 25-29.

Kaul, Flemming 2018b: Folkeminderne og arkæologien 2. Skalk nr. 5, s. 20-27.

Klintberg, Bengt af 1972: Svenska folksägner. Stockholm.

Kristensen, Evald Tang 1892-1901: Danske Sagn som de har lydt i folkemunde. Gammel rekke. Bind I-VI. Århus.

Kristensen, Evald Tang 1928-1939: Danske Sagn som de har lydt i folkemunde. Ny reeke. Bind I-VI. Århus.

Kulturhistorisk leksikon for nordisk middelalder. Fra vikingetid til reformationstid 1956-1978. J. Danstrup (udg.). København.

Larsson, Lars 2001: A building for ritual use at Uppåkra. Antiquity vol. 75, s. 679-680.

Laursen, Kent Otte 2005: Initiationsscenarier på nordiske guldbrakteater - En ikonografisk tolkning af udvalgte B-brakteater. Upubliceret speciale. Aarhus Universitet.

Laursen, Kent Otte 2007: Victoria-brakteaterne og førkristne indvielsesriter. LAG 8, s. $25-66$.

Laursen, René 2013: Guldkvinden. Skalk nr. 3, s. 14-15.

Laursen, René 2018: Nyt fra Guldhullet - en bornholmsk kultplads. Fund \& Fortid nr. 1, s. $10-14$

Leach, MacEdward 1963: Folklore of Jamaica. A Survey. Schweizerisches Archiv für Volkskunde $=$ Archives suisses des traditions populaires, vol. 59, s. 61-81.

Leclercq, Jacqueline 1975: De la Terre-Mère à la luxure. A propos de "La migration des symbols". Cahiers de civilisation médiévale, vol. 18, 69, s. 37-43.

Lecouteux, Claude 2011: Phantom Armies of the Night. The Wild Hunt and the Ghostly Processions of the Undead. Rochester.

Lindow, John 2014: Trolls. An unnatural history. London.

Luyster, Amanda 2001: The Femme-aux-Serpents at Moissac: Luxuria (Lust) or a Bad Mother? I: S. Asirvatham, C.O. Pache \& J. Watrous (red.) Between Magic and Religion: Interdisciplinary Studies in Ancient Mediterranean Religion and Society. Oxford, s. 165-191.

Lövkrona, Inger 1982: Det bortrövade dryckeskärlet. En sägenstudie. Lund.

Lövkrona, Inger 1988: 'Lilla vit skänk hit'. En studie över Trolleättens vapenförklaringssägen. Saga och sed, s. 51-83.

Machál, Jan 1918: Slavic Mythology. Mythology of all races, vol. III. Boston.

Mackeprang, Mogens 1941: Danmarks middelalderlige Døbefonte. København.

Mackeprang, Mogens B. 1935: Menschendarstellungen aus der Eisenzeit Dänemarks. Acta Archaeologica, vol. 6, s. 228-249.

Mackeprang, Mogens B. 1943: Om de saakaldte 'guldgubber'. Fra Nationalmuseets Arbejdsmark, s. 69-76.

Mannhardt, Wilhelm 1875: Wald- und Feltkulte. Erster Teil. Der Baumkultus der Germanen und ihrer Nachbarstämme. Berlin.

Mitchell, Stephen 2009: Odin, Magic, and a Swedish Trial from 1484. Scandinavian Studies, vol. 81, 3, s. 263-286.

Mittman, Asa S. 2003: Headless men and hungry monsters. Paper given at Stanford University on March 13, 2003. http://sarumseminar.org/meetings/2003-03-MittmanHeadless-Men-and-Hungry Monsters.pdf

Nielsen, Finn Ole \& Margrethe Watt 2018: Pre-Christian offerings from Guldhullet near Smørenge on Bornholm, Denmark. Acta Archaeologica, vol. 89, 1, s. 77-89. 
Nyborg, Ebbe 1978: Fanden på vaggen. Højbjerg.

Obrist, Barbara 1976: Les deux visages du diable. I: Cabinet des estampes (udg.): Diables et diableries. La représentation du diable dans la gravure des XVe et XVIe siècles. Genéve, s. $19-29$.

Odenius, Oloph 1961: Den döde modern som däggas av ormar. Danske Studier, s. 6-16.

Olrik, Axel 1901: Odinsjægeren i Jylland. Dania: Tidsskrift for Folkemål og Folkeminder, bind 8, s. 139-173.

Olrik, Axel \& Hans Ellekilde 1926-1951: Nordens Gudeverden. Bd. 1: Vetter og Helligdomme. København.

Persson, Charlotte Price 2018a: Unikke fund vælter op af Bornholms 'Guldhul'. Videnskab.dk: https://videnskab.dk/kultur-samfund/ unikke-fund-vaelter-op-afbornholms-guldhul

Persson, Charlotte Price 2018b: Arkæolog på jagt efter lange patter og trolde i folkesagn. Videnskab.dk: https://videnskab.dk/kultur-samfund/arkaeolog-paa-jagt-efter-langepatter-og-trolde-i- folkesagn

Phillips, Kim M. 2018: The Breasts of Virgins. Sexual Reputation and Young Women's Bodies in Medieval Culture and Society. Cultural and Social History, vol. 15:1, s. 1-19.

Röhrich, Lutz 1965: Die Frauenjagdsage (Mot. E 501.5.1. Wild hunter pursues a woman). Laographia vol. 22, s. 408-423.

Röhrich, Lutz 1967: Erzählungen des späten Mittelalters und ihr Weiterleben in Literatur und Volksdichtung bis zur Gegenwart. Band II. Bern \& München.

Rolf Krakes Saga 2016: Oldtidssagaerne, bind. 2. Annette Lassen (red.): København.

Schmidt, August F. 1932: Danmarks Kampesten i Folkeoverleveringen. København.

Schjødt, Jens Peter 2008: Initiation between Two Worlds. Structure and Symbolism in PreChristian Scandinavian Religion. Odense.

Schön, Ebbe 2004: Asa-Tors hammare. Gudar och jätter i tro och tradition. Stockholm.

Sturluson, Snorri 2013: Edda. Ved Kim Lembek og Rolf Stavnem. København.

Thrane, Henrik 2005: Romerske og germanske småfigurer. I: T. Capelle \& C. Fischer (red.): Ragnarok. Odins Verden. Silkeborg, s. 33-40.

Tybjerg, Tove 2010. Religionsforskning før og nu. Bind 1: Historiske rødder. København.

Vries, Jan de 1931: Contributions to the Study of Othin. Especially in his Relation to Agricultural Practices in Modern Popular Lore. Helsinki.

Voss, Olfert 1990: Hjemlige bronzemænd. I: P. Kjærum \& R.A. Olsen (red.): Oldtidens ansigt. Til Hendes Majestet Dronning Margrethe II 16. april 1990. København, s. 138.

Vølvens spådom 2018: Den poetiske Edda. Rolf Stavnem (overs.). København.

Watt, Margrethe 1991: Sorte Muld. Høvdingesæde og kultcentrum fra Bornholms yngre jernalder. I: P. Mortensen \& B.M. Rasmussen (red.): Fra Stamme til Stat $i$ Danmark 2. Høvdingesamfund og Kongemagt. Højbjerg, s. 89-106.

Watt, Margrethe 1992: Die Goldblechfiguren (,guldgubber') aus Sorte Muld. I: K. Hauck (udg.): Der historische Horizont der Götterbild-Amulette aus der Übergangsepoche von der Spätantike zum frühmittelalter. Göttingen, s. 195-227.

Watt, Margrethe 2008: Guldgubber. I: C. Adamsen, U. Lund Hansen, F.O. Nielsen \& M. Watt (red.): Sorte Muld. Rønne, s. 42-53.

Watt, Margrethe 2015:"Christian" gestures and fertility cult (?) reflected in the iconography of 6th century Southern Scandinavia. I: C. Ruhmann \& V. Brieske (red.): 
Dying Gods - Religious beliefs in northern and eastern Europe in the time of Christianisation. Stuttgart, s. 177-190.

Weir, Anthony \& Jim Jerman 1986: Images of lust. Sexual carvings on medieval churches.

London.

Zachrisson, Torun 2003: Den hängde med halsringen. Om en figurin från järnåldern funnen vid Kymbo Storegården i Västergötland. Fornvännen, s. 89-97.

Zingerle, Ignaz V. 1891: Sagen aus Tirol. Innsbruch. 